\title{
The Coptic Wizard's Hoard
}

\author{
Paul Mirecki \\ University of Kansas
}

W

ithin the large collection of ancient manuscripts at the University of Michigan there is a group of Coptic papyri which appears to have been a hoard or library of ancient magical texts. ${ }^{1}$ Produced by five copyists sometime in the fourth through seventh centuries and originating from a now unknown location in Egypt, the collection was brought to the British Museum by Sir E. A. Wallis Budge in February 1921 for restoration by C. T. Lamacraft; in August of that year, it underwent philological examination by the Coptic lexicographer Walter E. Crum, and was later forwarded to the University of Michigan. ${ }^{2}$

Apart from the importance of the texts for the study of Coptic magic and related fields, the wizard's hoard provides researchers with a rare glimpse

'I am preparing a comprehensive facsimile and critical text edition of the wizard's hoard. I am indebted to several people for their help with this work. Since 1986, Ludwig Koenen has generously provided access to both the papyrus collection and the research library at the University of Michigan. The Near Eastern Studies Department at the University of Michigan assisted in the costs of photography. In July 1993, Dr. Thomas S. Pattie provided access to the British Museum archives in London; and in 1990, 1992, and 1993, the University of Kansas General Research Fund and the Kansas School of Religion (Lawrence) provided grants supporting my on-site research. I gratefully acknowledge that I have received helpful comments on issues related to this study from William M. Brashear (Berlin), Morton Smith (New York), and the Coptic Seminar of the Institute for Antiquity and Christianity, held in March 1989 (Claremont Graduate School).

${ }^{2}$ Stephen Emmel suggested a range of the fifth through seventh centuries for all hands (personal correspondence with the author, 1989). In a conversation in 1988, Professor Koenen dated one of the codex hands (scribe three) to the fourth century. 
into the activities and literary production of a "magical workshop"3 in which several individuals, perhaps working together, produced a written collection of magical texts in loose-leaf scroll and book form, including at least one folded amulet. ${ }^{4}$

\section{The Nature and Extent of the Wizard's Hoard}

In order to understand the nature and original function of the collection, it is crucial to discuss whether some manuscripts have been lost or displaced from the collection. There is no internal textual evidence, such as an index or other indicators of cross-referencing between the texts, to suggest that the current collection is either complete or incomplete. Except for the lost opening lines of the two texts copied onto the two smaller scrolls, ${ }^{5}$ all of the copied texts are complete; even when a text is copied two or three times within the collection, each of those copies is complete, giving no reason to suppose that a significant portion of the collection is now lost.

Although the collection now may be intact and in its originally complete form, it has suffered some dismemberment in the modern period since its discovery. In 1930, William $\mathrm{H}$. Worrell published a brief description of the collection along with a partial transcription and translation of one of its texts. ${ }^{6}$ In that study, Worrell noted that the collection consists of eleven manuscripts and he assumed that it was complete. In the fall of 1986, however, while perusing the large collection of Coptic manuscripts in the Michigan collection, I came across twenty-seven fragments of the damaged

\footnotetext{
${ }^{3}$ On magical workshops, see Richard Wünsch, Antikes Zaubergerät aus Pergamum (Jahrbuch des Kaiserlich Deutschen Archäologischen Instituts, Ergānzungsheft 6; Berlin: Reimer, 1905); C. Julian, “Au champ magique de Glozel," Revue des études anciennes 29 (1927) 157 n. 4; S. Agrell, Die pergamenische Zauberscheibe und das Tarockspiel (Lund: n.p. 1936); Alphons A. Barb, "The Survival of the Magic Arts," in Arnaldo Momigliano, ed., The Conflict Between Paganism and Christianity in the Fourth Century (Oxford: Clarendon, 1963) esp. 112-13; and Arthur Darby Nock, "Greek Magical Papyri," in Zeph Stewart, ed., Arthur Darby Nock: Essays on Religion and the Ancient World (2 vols.; Oxford: Clarendon, 1972) 1. 176-94. Christopher Faraone and Roy Kotansky ("An Inscribed Gold Phylactery in Stamford, Connecticut," Zeitschrift für Papyrologie und Epigraphik 75 [1988] 257 n. 2) describe a cache of nineteen silver phylacteries.

${ }^{4}$ P. Mich. inv. 1294; on the Greek magical papyri, see PGM; Theodor Hopfner, Griechischägyptischer Offenbarungszauber (1921-24; 2 vols.; reprinted Amsterdam: Hakkert, 197483); Robert W. Daniel and Franco Maltomini, eds., Supplementum Magicum (2 vols.; Opladen: Westdeutscher Verlag, 1990-92); and Hans Dieter Betz, The Greek Magical Papyri in Translation (Chicago: University of Chicago Press, 1986). On the Coptic magical papyri, see Angelicus M. Kropp, Ausgewählte koptische Zaubertexte (3 vols.; Brussels: Fondation Égyptologique Reine Elisabeth, 1930-31); and Marvin W. Meyer and Richard Smith, eds., Ancient Christian Magic: Coptic Texts of Ritual Power (San Francisco: Harper, 1994).

${ }^{5}$ P. Mich. inv. 600, 601.

${ }^{6}$ William H. Worrell, “A Coptic Wizard's Hoard,” AJSL 46 (1930) 239-62.
} 
and partial remains of a folded papyrus amulet, restored it, and later identified it as part of the wizard's hoard, thus raising the number of extant manuscripts to at least twelve. ${ }^{7}$ The inventory files for the papyrus collection at the University of Michigan, which quote from Crum's notes (dated August 1921), only refer to the eleven manuscripts numbered from 593 to 603 and state that all manuscripts related to the collection were conserved by C. T. Lamacraft at the British Museum. ${ }^{8}$ This suggests that both Crum and Lamacraft knew of only eleven manuscripts. Thus it is possible that some manuscripts, like the displaced and only recently identified and conserved amulet, unknowingly had been separated from the collection or lost before they reached the British Museum. In addition, the haphazard numbering system for taking inventory of the twelve manuscripts-P. Mich. inv. 593-603, 1294-does not correspond to the inner logic of the collection.

Given these limitations on present scholars' knowledge of the size of the collection at the time of its discovery, one need not assume that it originally comprised a rigid canon of only eight texts ${ }^{9}$ on twelve manuscripts. Rather, the contents of the collection probably expanded and contracted as the holy men, working alone or together, found some texts to be useful (which then were added or retained) and other texts no longer to be useful (which then were removed from the collection).

\section{Codicological and Textual Relations}

The collection consists of twelve manuscripts containing as many as eight texts written by five scribes. Some of the texts were copied two and three times by the copyists. Three of the hands are practiced, with one (scribe three) tending toward a bookish style; together the three copied a single lengthy text onto a twenty-page codex. ${ }^{10} \mathrm{~A}$ fourth hand, also practiced but varying considerably in size and exhibiting a pronounced fluidity in style, copied as many as four texts onto a large scroll, ${ }^{11}$ another text onto a now fragmentary scroll, ${ }^{12}$ and still yet another text onto a final and

${ }^{7}$ P. Mich. inv. 1294; I am indebted to Professor Koenen for his patience and expert guidance during the restoration process.

8In July 1993, I perused the British Museum's acquisition records for 1920 through 1932 and found no mention of the hoard. Thomas S. Pattie, in conversation with the current conservators, suggested that the hoard was sent privately to Lamacraft for restoration, and was never the property of the British Museum.

${ }^{9}$ The collection contains as many as eight separate texts. I have not yet determined the literary relationships between the textual units on the various sections of the manuscripts.

${ }^{10} \mathrm{P}$. Mich. inv. 593; scribe one wrote on pages 1-3, scribe two wrote on pages 4-12, scribe three wrote on pages 13-18, and then scribe one finished the codex by writing on pages 1920.

${ }^{11}$ P. Mich. inv. 602.

${ }^{12} \mathrm{P}$. Mich. inv. 600. 
now fragmentary scroll. ${ }^{13}$ The fifth hand, clearly unpracticed, ${ }^{14}$ demonstrates little physical control over the writing instruments and materials ${ }^{15}$ and copied as many as five texts onto a diverse set of eight papyrus sheets. ${ }^{16}$

It is not clear whether the collection was made at one time by the five scribes or whether it gradually grew over a period of time in the hands of several copyist-owners. It appears that parts of two independent and separate text collections, one in a single codex format and one in a triple scroll format, were crudely copied and edited together onto scrap papyrus sheets by a person who had little writing ability. ${ }^{17}$ The three scribes who copied the lengthy text onto the codex apparently shared no texts with scribe four, while scribe five copied texts from each of the four other scribes, that is, from the two earlier collections. Worrell suggests that the three scribes of

${ }^{13} \mathrm{P}$. Mich. inv. 601.

${ }^{14}$ Worrell ("Wizard's Hoard," 239-40) describes the hand as that of "a negligent paralytic or a very young child." On "slow writers" and "rough, untutored hands" as a trademark of children, see the discussions in Eric G. Turner, Greek Papyri: An Introduction (Oxford: Clarendon, 1968) 88-89.

${ }^{15}$ If scribe five was in fact an illiterate child or adult, his or her illiteracy may have been used as a guarantee to ensure the secrecy of the sacred traditions gathered together by one or more of the other scribes (observation by Morton Smith, personal conversation with the author, 1987). For discussions and bibliographies of current debates concerning ancient Greek literacy and the participation of illiterates in magic, see Christopher A. Faraone, "The Agonistic Context of Early Greek Binding Spells"; and C. R. Phillips III, "Nullum Gimen sine Lege: Socioreligious Sanctions on Magic"; in Christopher A. Faraone and Dirk Obbink, eds., Magika Hiera: Ancient Greek Magic and Religion (New York: Oxford University Press, 1991) 23 n. 10, and 263,272 n. 23, respectively.

${ }^{16} \mathrm{P}$. Mich. inv. 594-99, 603, 1294.

${ }^{17} \mathrm{On}$ the difficulty of reconstructing historical and social contexts that produced specific manuscripts, see the guidelines and discussions in Turner, Greek Papyri, 74-96. See also Peter Brown, "The Rise and Function of the Holy Man in Late Antiquity," JRomS 61 (1971) 80-101; Adolf Erman, "Ein koptischer Zauberer," Zeitschrift für Ägyptische Sprache und Altertumskunde 33 (1895) 43-46; Moses Finley, Ancient History: Evidence and Models (New York: Viking, 1986) 35-36; and Jonathan Z. Smith, "The Temple and the Magician," in idem, Map is Not Territory: Studies in the History of Religions (Studies in Judaism in Late Antiquity 23; Leiden: Brill, 1978) 172-89. Worrell speaks of a "wizard's hoard" but gives no evidence that this is the collection of only one individual, nor does he discuss the ambiguous concept "hoard." Papyrologists traditionally speak of an "archive" (Turner, Greek Papyri, 47-48, 7778). Perhaps the less value-laden "collection," or even the more positive "anthology" or "library" (Nock, "Greek Magical Papyri," 1. 76-77) are more useful terms. Note Betz's positive evaluation (Greek Magical Papyri in Translation, xli-xlii) of the Anastasi magical papyri as "systematic collections. . . [by] a scholar, probably philosophically inclined. . . a bibliophile and archivist" living in ancient Thebes. See also the literature and comments on "wizard's libraries" in Walter E. Crum, "Magical Texts in Coptic-II," JEA 20 (1934) 200. In his excellent study, Fritz Graf ("Prayer in Magic and Religious Ritual," in Faraone and Obbink, Magika Hiera, 195) comments on the social isolation of such holy men ("the community is absent from the magical praxis. . . the magician is an isolated individual"), but does not take into account the evidence for magical workshops in which several individuals worked together to serve a community. Withdrawal from the community may be due to demands for ritual purity and secrecy. 
the codex and scribe five were mutually dependent on a now lost common manuscript. ${ }^{18}$ Two of the most striking common features among the manuscripts is that none appears to have any significant signs of wear from practical use or textual alterations by later hands, suggesting that the collection was used little, if at all.

The amulet ${ }^{19}$ provides internal evidence that the large scroll, ${ }^{20}$ or Worrell's lost common source, was the magical source book from which individual amulets were written, suggesting that the other two rolls (recorded by scribe four) and the codex were also used as source books. It is difficult to determine why this particular amulet remained with the collection, unless we are to assume that it had not been given to a client yet, or that it was used personally by one of the scribes.

\section{The Magical Book and its Two Texts ${ }^{21}$}

The codex itself is constructed from four papyrus sheets cut from a blank roll, stacked, and then folded together to form a standard four-fold quire (quaternio) of eight leaves or sixteen pages (pages 1-16), to which was added a single-sheet quire (unio) of two leaves or four pages (pages 17-20). ${ }^{22}$ It is not clear whether the two quires were bound together; perhaps the quires were placed unbound into a cover comprised of the blank papyrus sheet with the same dimensions as the codex leaves. ${ }^{23}$ The two quires form a nearly square codex of twenty pages that measure between 15.3 and $16.0 \mathrm{~cm}$ (vertical) and between 15.3 and $17.3 \mathrm{~cm}$ (horizontal). There is no evidence that the quires were bound.

The book contains the longest text in the collection, followed by a short invocational prayer with ninety-five lines of magical words, together filling the twenty-page codex with three hundred and thirty-eight lines (approximately twenty-two letters per line). The two texts, translated below, can be outlined in the following fashion.

\section{Outline of Text One}

1. The prayer: invocations, credentials, and requests: $1.1-4.14 \mathrm{a}$

a. Invocation to the highest deity: $1.1-11$

${ }^{18}$ Worrell, "Wizard's Hoard," 241.

${ }^{19} \mathrm{P}$. Mich. inv. 1294.

${ }^{20} \mathrm{P}$. Mich. inv. 602.

${ }^{21}$ P. Mich. inv. 593.

${ }^{22} \mathrm{On}$ the quaternio as a standard quire size, and on codices with a single unio quire accompanying one or more quires of larger gatherings, see the discussions in Turner, Greek Papyri, 12-14; and Eric G. Turner, The Typology of the Early Codex (Philadelphia: University of Pennsylvania Press, 1977) 55, 60.

${ }^{23}$ Concerning papyrus fiber directions, the codex was not constructed according to convention, but the first four sheets were placed into their quire so that facing pages $(2-3,4-5,6-$ $7,10-11,12-13,14-15$, and 16-17) had opposing fiber directions. Such facing pages lost a substantial amount of ink through abrasion as the opposing fibers wore against each other (Turner, Greek Papyri, 15; and idem, Typology, 54-58). 
b. Request ("grant to me everything"): 1.12-13

c. Invocation to the seven archangels: $1.14-16 \mathrm{a}$

d. Request ("act on my behalf"): $1.16 \mathrm{~b}$

e. Credentials of the holy man ("I am Seth"): 1.16c-2.2

f. The secret Hebraic names of the twenty-one powers: 2.3-9a

g. Description of the twenty-one powers: $2.9 \mathrm{~b}-15 \mathrm{a}$

h. Request and description: $2.15 b-3.10$

i. Credentials of the holy man ("I am Seth"): 3.11-17a

j. Editorial comment on ritual purity: $3.17 \mathrm{~b}-4.1 \mathrm{a}$

k. Credentials of the holy man ("I am Seth"): $4.1 \mathrm{~b}-8 \mathrm{a}$

1. Editorial comment on ritual purity: $4.8 b-14 a$

2. Ritual instructions: $4.14 b-5.19 a$

a. Ritual action and a promise: $4.14 \mathrm{~b}-18 \mathrm{a}$

b. Ritual action (the "hawk's egg ritual"): $4.18 \mathrm{~b}-5.8 \mathrm{a}$

c. Instructions and promises: $5.8 \mathrm{~b}-19 \mathrm{a}$

3. A list of thirty-two tricks and prescriptions: $5.19 \mathrm{~b}-11.12 \mathrm{a}$

4. Instructions, promises, and ritual preparations: $11.12 \mathrm{~b}-12.5$

\section{Outline of Text Two}

1. Magical words with Demotic letters (9 lines): $12.6-14$

2. An invocation: $13.1-15.7$

3. Magical words (ninty-five lines): $15.8-20.18$

\section{The Two Texts ${ }^{24}$}

[1.1] God, Lord Lord, ${ }^{25}$ all powerful One, ${ }^{26}$ whose body has / the appearance of fire which is light / in the hidden things. The one [1.5] who

\footnotetext{
${ }^{24}$ The translation of the Coptic text is my own and follows that of Worrell as closely as possible. I have added words in parentheses in order to clarify the intent of the often obscure Coptic sentences. Numbers in parentheses designate items in the thirty-two part list; numbers in square brackets designate page and line numbers; and vertical strokes indicate separate lines; I also have introduced paragraph divisions. The translation presented here is based on my own transcription of the text found in the codex, rather than on my transcription of the nearly identical text found on the scrap papyrus sheets. This contrasts with Worrell's "reconstructed" Coptic text which is a collation of the two complete, but slightly varying versions of this text. Worrell's text does not exist in any of the manuscripts (note his comments in "Wizard's Hoard," 241) and his critical commentary is sketchy. My selection of the text in the codex, rather than the nearly identical text on the scrap sheets, does not suggest that the codex preserves a better form of the text. In fact, the differences between the two versions are minimal (for example, P. Mich. inv. 598 includes six more lines of concluding narrative).

${ }^{25}$ I understand the repetition of titles to be deliberate epanadiplosis for emphasis (see Egyptian geminates), the first having an intensive adjectival function, rather than a scribal dittography or a simple repetition of the same title. The same phenomenon occurs in Hebrew and Greek (see Luke 6:46); see BDF §493.1.

26"All Powerful One" is a translation of the Greek Pantocrator ( $\pi \alpha v \tau o \kappa \rho \alpha \tau \omega \rho)$; see the discussion and literature cited in Daniel and Maltomini, Supplementum Magicum, 1. 29 lines 5-6 (text and commentary).
} 
is born of flesh does not know your name, / but only you yourself (know it), ${ }^{27}$ the entire way / of wisdom ${ }^{28}$ who alone is / from the aeons of light, who is unknowable, / (and) is surrounded by all of the powers [1.10] who are each appointed over your / work and your service. / Grant to me everything related to this prayer and / (to) every (ritual) action which I perform! /

You seven angels, each [1.15] appointed over his work and his / service, act on my behalf! (For) I am Seth ${ }^{29}$ [2.1] the son of Adam, ${ }^{30}$ the first revelation / of the unformed fingers! $!^{31}$ / Michaēl, Gabriēl, Raphaēl, Ouriēl, / Saraphouel, Souriêl, Anaēl; and also [2.5] his other ministrants: Amoel, Anathaēl, / Ananaēl, Anaēl, Phriēl, Thriēl, / Ariēl, Israēl; and the other authorities: / Mosul, Osul, Phaēl, Ioel, Arphaèl, / Tremaēl.

All of these great ones are the [2.10] powers who are in the presence of / this unseeable light / (and are) the angels who are in the height, those of the night / and those of the day, 32 each of whom / is appointed over his work and the [2.15] service.

Hear our ${ }^{33} /$ authority which is over you, all of his ministrants [3.1] who are called (by name) by / those above them, even you great archangels / who are strong in your power, you whose / names were first given to you, ${ }^{34}[3.5]$ that is, (you) angels who call ${ }^{35}$ all of the special names / which

${ }^{27}$ See Gen 3:13-15.

${ }^{28}$ The wisdom theme enters again at 4.13 .

${ }^{29}$ On "Seth the Son of Adam," see the revised version of Birger Pearson, "The Figure of Seth in Gnostic Literature," in idem, Gnosticism, Judaism, and Egyptian Christianity (Minneapolis: Fortress, 1990) 52-83; and the texts and literature cited in Paul A. Mirecki, "The Figure of Seth in a Coptic Magical Text," in David W. Johnson, ed., Acts of the Fifth International Congress of Coptic Studies: Washington, 12-15 August 1992, vol. 2: Papers from the Sections (Rome: C.I.M., 1994).

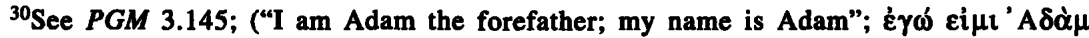

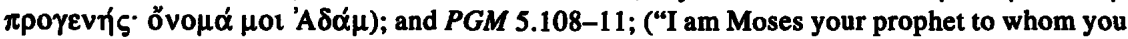

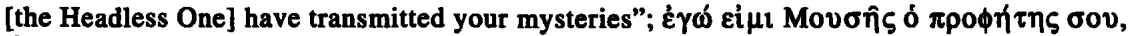
$\left.\$ \pi \alpha \rho \varepsilon \delta \omega \kappa \alpha \varsigma \tau \alpha^{\alpha} \mu v \sigma \tau \eta \dot{\rho} \rho \dot{\alpha} \sigma o v\right)$; for texts and bibliography on Moses, see Hans Dieter Betz, "Magic and Mystery in the Greek Magical Papyri," in Faraone and Obbink, Magika Hiera, 252, 259 n. 63.

${ }^{31}$ See Dan 2:44-45. Worrell translates NaЛ2астос लттннве as "unformed hands," interpreting fingers as a metaphor for hand. I thank Hans-Martin Schenke for his suggestion that $\overline{\boldsymbol{N}} T$ HHBE be interpreted and translated literally as fingers (personal communication with the author, 1992).

${ }^{32}$ The text does not specify which angels are of the night and which are of the day.

${ }^{33}$ Here the holy man speaks to the eight ministrants in a corporate plural, and so identifies with the authority of the seven archangels.

${ }^{34}$ The meaning is obscure; the archangels were either the first of the angelic creations to be named by their creator, or the reference is to the prayer itself, in which the names of the seven archangels were the first of the secret Hebrew names to be spoken by the holy man in his opening invocations.

${ }^{35}$ The text twice makes reference to angels who "are called" [3.1] and who "call" [3.5]. Apparently the seven archangels call the names of the angels below them on the angelic 
are written (here) in Hebrew, / the language of heaven, ${ }^{36}$ in order that they ${ }^{37}$ might hear the / one who will activate this $\operatorname{prayer}^{38} /$ (and that) they might bring to pass for him everything which he will perform [3.10] in purity and chastity of ritual. ${ }^{39} /$

I am Seth the son of Adam. / I have purified myself forty days / until its power is revealed / and the power of its Hebrew (language) [3.15] and all of its manipulations, so that it can / assist in every action which I / perform. Perform it while you [4.1] are pure and in awe. ${ }^{40}$

I am / Seth the son of Adam, to whom have been / revealed ${ }^{41}$ the

hierarchy. The "call" implies a position of hierarchical-and perhaps emanational-priority and authority over those who hear the call. This reference to interangelic calling is found in the astrological tradition; see Manilius Astronomica 1.263-74 (LCL; trans. G. P. Goold; Cambridge, MA: Harvard University Press, 1977) 25-26; ("Taurus who calls. . . the Gemini").

${ }^{36} \mathrm{On}$ Hebrew as the language of heaven, the divine language with which God conversed with Adam, Eve, and the serpent, see T. Naph. 8.3-6 ("the holy language, the Hebrew language"); Jub. 12.25-27 ("Hebrew. . . the tongue of the creation"; see also Jub. 3.28); and Gen. R. 18.6, 31.8 (see also 1 Cor 13:1). For a rabbinic debate on whether Adam spoke Hebrew or Aramaic, see b. Sanh. 38b (on Ps 139:19). See also'Louis Ginzberg, who lists Jewish and Christian sources in his The Legends of the Jews (7 vols.; Philadelphia: Jewish Publication Society, 1909-38) 5. 205-6; Peter Hayman, "Was God a Magician?" JJS 40 (1989) 225-37, and Kropp, Koptische Zaubertexte, 3. 133-34 \$8 230-31. References to the Hebrew language in Greek and Demotic magical texts can be found at PGM 4.3084-85, 5a.474-75, 13.80-84, 145-50, 455-60, 590-95, 975-79, and 22b.18-21. On foreign words in magical texts and Hebrew and Aramaic words transliterated into Greek in the Gospel of Mark, see Morton Smith, Jesus the Magician (New York: Harper \& Row, 1978) 128, 204.

${ }^{37}$ The antecedent is presumably the eight ministrants and six authorities who are under the authority of the seven archangels and the divinized holy man.

${ }^{38}$ The assumption is that the twenty-one angelic powers understand the Hebrew language. Thus, the holy man has access to the twenty-one powers and influence over them, because he can communicate with them in their primary language. They also understand human languages since they are in fact addressed here in Egyptian (Coptic, elsewhere Demotic) and elsewhere in other languages. The second-century satirist Lucian of Samosata refers to the belief that the lower demons could speak the language of the country of their origin, "the demon responds in Greek or a foreign tongue, depending on his country of origin" (Philops. 14-18); also compare the possibly Latin-speaking Legion of foreign mercenary demons in Mark 5:1-13.

${ }^{39}$ That is, the angels "will bring to pass in human reality anything of which the holy man performs in a ritual action as a representational model or type" (Morton Smith, personal correspondence with the author, 1987).

${ }^{40}$ The "it" in this section refers to the prayer mentioned in the preceding paragraphs. The last imperative statement appears to be an editorial comment.

${ }^{41}$ The reference is to Adam who received the antediluvian teaching and delivered it to his son Seth. Seth's transmission of that teaching to his offspring was a common theme in antiquity, especially in gnostic texts, and was ultimately derived from Jewish sources such as the apocryphal Adam literature (see Pearson, "Seth in Gnostic Literature," 52-83, esp. 71-76), but is otherwise unknown to me in magical texts. Of the three references in this text to the biblical Seth, this last reference has the closest conceptual parallels to the gnostic tradition with its reference to Adam's-and Seth's-reception of revelation. There is no clear indication in this passage, however, or elsewhere in this text, that the author knows of the gnostic world view. 
virtues $^{42}$ and the mysteries ${ }^{43} /$ and its manipulations ${ }^{44}$ and the power of these [4.5] arts, which are honored more than the other / prayers that are concerned with these secret names and / all the rest, ${ }^{45}$ for $I$ am in agreement with its / operations.

Not every man can perform / it except (one) who is sufficiently pure, [4.10] who is perfected in / all of its secret names and its powers, / for this (prayer) causes a spirit to rest / upon $\mathrm{him}^{46}$ and (gives him a measure of) wisdom more than / any man. ${ }^{47}$

You are to recite it seven [4.15] times over some honey and some / licorice root. It sets a reminder / within you, forever and ever, / in your mind and spirit. Take [5.1] a hawk's ggg $^{48}$ and fry / it, then eat it over the $/$ honey, purifying yourself for forty / days until its $\operatorname{mind}^{49}$ appears [5.5]

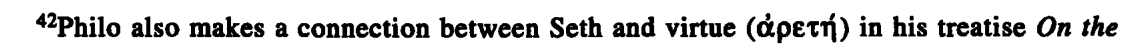
Posterity and Exile of Cain. His comments on Gen 4:17-25 observe that all lovers of virtue are descendents of Seth (Poster. C. 42) and that Seth is the "seed of human virtue" (ibid., 173;

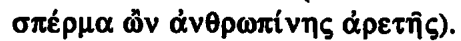

${ }^{43}$ Compare PGM 5.108-11 ("I am Moses your prophet to whom you [the Headless One] have transmitted your mysteries"). On the use of the word mystery ( $\mu \nu \sigma \tau \eta_{p 10 v)}$ in magic, see the comments by Hans Dieter Betz, "The Formation of Authoritative Tradition in the Greek Magical Papyri," in Ben F. Meyer and E. P. Sanders, eds., Jewish and Christian Self-Definition, vol. 3: Self-Definition in the Graeco-Roman World (Philadelphia: Fortress, 1982) 164, 237 nn. 10-18. See also Betz, "Magic and Mystery in the Greek Magical Papyri," 249-54.

${ }^{44} \mathrm{That}$ is, those ritual actions that attend the prayer.

${ }^{45}$ The reference to "the other prayers that are concerned with these secret names and all the rest" is perhaps an allusion to similar spells and prayers, circulating freely as texts or employed by competing holy men.

${ }^{46}$ That is, the holy man who activates the prayer.

${ }^{47}$ The wisdom theme was introduced at $1.6-7$. This sentence also seems to be a secondary editorial comment concerning ritual purity.

${ }^{48}$ On the use of a hawk's egg in ritual, see The Demotic Magical Papyrus of London and Leiden (3 vols.; ed. Francis Llewellyn Griffith; London: Grevel, 1904-9) 14.115, which describes a concoction of hawk's egg and myrrh rubbed on the eyes. For its mention in a spell see $P D M$ 14.620-26, which describes a hawk's egg in the mouth of the deity who speaks. On the preparation of a concoction using a bird's egg and honey, along with other elements, to be smeared on genitals in a love and sex spell, see PGM 36.283-94; and on the magical use of eggs smeared with toad's blood, see Horace Epodes 5. Two eggs and the eyes of a black cat are part of a magical love ritual nearly performed by the hapless polylingual monk Salvatore for the love of the unnamed town girl in Umberto Eco's historical novel The Name of the Rose (trans. William Weaver; New York: Harcourt Brace Jovanovich, 1983) 326-32.

${ }^{49}$ This is one of only two occurrences of the Greek vov̧ known to me in Coptic magical papyri; the other is in Rossi's "Gnostic" Tractate (1.5), a Coptic magical book destroyed in 1904 in a fire at the Biblioteca Nazionale in Turin. See Marvin W. Meyer, "Rossi's 'Gnostic' Tractate," Occasional Papers of the Institute for Antiquity and Christianity 13 (1988) and the literature cited there. Worrell suggests that the reference might be to a scrying ceremony in which the reflective surface of the egg yolk became the mirror of thoughts in the mind of the self-hypnotized gazer, but here the egg is to be fried and eaten ("Wizard's Hoard," $257 \mathrm{n.}$ ); compare PGM 3.590-610; 5.459-69; 13.791-94; 13.173, 487; and Apuleius Apologia (or De magia) 42-43 ("the boy's mind, when awakened, quickly applies itself to the business of 
to you, in cleanliness and purity / for forty days, before you begin (the ritual, with) / your garments / cleansed. Perform it as a / response, ${ }^{50}$ for it is highly honorable (and) [5.10] a great grace is in it. / For it removes the anger / of every married $\operatorname{man}^{51}$ (and) / it heals the bites of beasts / and reptiles. ${ }^{52}$ Do not despise [5.15] it because of these great secret names, / for its powers are great. / It causes every (evil) thing to disappear. ${ }^{53} /$ It saves you from those who hate and / from every curse. ${ }^{54}$

(1) Concerning the bite [6.1] of a reptile: recite it over some water / and have him drink it.

divination"); compare Betz, Greek Magical Papyri in Translation, 109 n. 61. See the more detailed analysis of the passage in Paul A. Mirecki, "The 'NOUS' in the Greek and Coptic Magical Papyri: A Contribution to the Study of the 'NOUS' in Manichaeism" in Alois van Tongerloo, ed., Acta of the Symposium on the Manichaean Nous (Leuven: International Association for Manichaean Studies, 1994). On the scrying ritual, see the survey of theories and literature in Georg Luck, Arcana Mundi: Magic and the Occult in the Greek and Roman Worlds (Baltimore, MD: Johns Hopkins University Press, 1985) 254-56. The divination is also similar to a type of pyromancy (divination by fire) known as oöscopy in which a raw egg is broken over fire and its subsequent shapes are interpreted.

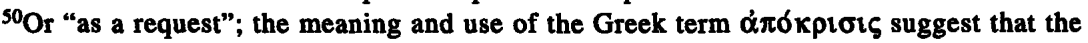
ritual is performed as a "response" to specific problems that arise unexpectedly. In the Greek magical papyri the term refers to a reply from a god (for example, "I call upon you. . . give an answer"; PGM 4.3221), or to an explanation of a ritual which is not to be given to anyone in order to keep its actions or invocations secret and thus to avoid interference once the ritual has begun (for example, "while performing the invocation, give answer to nobody"; PGM 2.24; see also PGM 5.399; 7.440, 726, 1011; 8.67; compare Mark 1:40-44; 7:32-36a; 11:33; further see Mark 14:60-61; 15:4-5; 16:8; and Luke 1:19-20, as suggested by Morton Smith in personal correspondence with the author, 1988). Gunther Roeder (Die ägyptische Religion in Texten und Bilden, vol. 4: Der Ausklang der ägyptischen Religion mit Reformation, Zauberei und Jenseitsglauben [Zurich: Artemis-Verlag, 1961] 223), however, translates the term with the German "meine Bitte," when it is found in a Coptic magical text in P. Carlsberg 52 (line 40); see the recent discussion in William M. Brashear, ed., Magica Varia (Brussels: Fondation Egyptologique Reise Élisabeth, 1991) 35, and the literature cited on pp. 16 and $25 \mathrm{n} .18$.

${ }^{51}$ This reference to the effectiveness of the prayer for troubles encountered by married men is in line with the general male orientation of the text. See the informative discussion of gender roles in relation to "pharmacology and magicoreligious assumptions" in John Scarborough, "The Pharmacology of Sacred Plants, Herbs, and Roots," in Faraone and Obbink, Magika Hiera, 161-62. Note the absence of gender specific language, in favor of a generalizing masculine formula, in a Greek protective charm for a woman client named Taiolles (P. Princeton 2.107) in Daniel and Maltomini, Supplementum Magicum, 1. 29 lines 6-8; see n. 77 below.

${ }^{52}$ There is no mention of bites from beasts in the list of prescriptions following this section, suggesting that this reference is general or purely formulaic. Bites from reptiles are mentioned in the first prescription.

${ }^{53} \mathrm{This}$ is probably a general promise for protection from evil, with exorcistic overtones, rather than a reference to the invisibility spells so popular in the Greek and Demotic texts.

${ }^{54} \mathrm{~A}$ common theme in magical texts is that some incantations can be used to break the power of malevolent incantations or potions used by one's enemy (see prescription 30 below; and PDM 14.309-15). 
(2) For jaundice: recite / it over some water which has some laurel / in it, and have him drink it and then wash him (with it) [6.5].55

(3) For one who is swollen:56 recite it over / some brick water, ${ }^{57}$ and have him drink it and then / wash him (with it).

(4) For ribs that are / in pain: recite it over some figs (and) / bind them on him.

(5) For the spleen: recite it [6.10] over some oil and anoint it.

(6) For the / headache: recite it over some oil and anoint / his temples..$^{58}$

(7) For one who has been troubled: / (recite it) over some oil of hiktanos, over some oil of / spanon, ${ }^{59}$ with some incense, and anoint him [6.15].

(8) For one who has fever: recite it over some / first-pressed oil ${ }^{60}$ and anoint him.

(9) For one / who suffers vertigo: recite it over some first-pressed [7.1] (oil) and anoint him.

(10) For one who fears / the night: recite it over some rain water / and wash him (with it).

(11) For one who does not (regularly) sleep: ${ }^{61} /$ recite it over some water and wash the / area around his bed (with it).

${ }^{55}$ On the role of the laurel plant ("Apollo's laurel, plant of presage"; PGM 6.40) in magic, see the discussion by Ludwig Deubner, Kleine Schriften zur klassischen Altertumskunde (Beiträge zur klassischen Philologie 140; Königstein: Hain, 1982) 401-3. Drinking and washing with water that has anise and laurel leaves in it is the supposed antidote promised to Lucius before he is transformed magically into an ass in Apuleius Met. 3.21-28.

${ }^{56}$ Worrell ("Wizard's Hoard," 257 n. 4) briefly discusses the Coptic term W 2 Y€ in relation to its use in the Demotic and Coptic medical papyri. See also Roy Kotansky, "Incantations and Prayers for Salvation on Inscribed Greek Amulets," in Faraone and Obbink, Magika Hiera, 113-14, 117, 133 nn. 71-74.

${ }^{57}$ Both bricks and water were common ritual objects and appear repeatedly in the Greek and Demotic magical texts, but this reference to "brick-water" (TWBE) remains obscure. See James Drescher, "Two Coptic Magical Ingredients," Bulletin de la Société d'archéologie copte 14 (1950-57) 59-61; and Oswald Hugh Ewart Burmester, The Egyptian or Coptic Church: A Detailed Description of Her Liturgical Services and the Rites and Ceremonies Observed in the Administration of Her Sacraments (Cairo: French Institute of Oriental Archaeology, 1967) $250-56$.

${ }^{58}$ On cures for headaches, see $P D M$ 18a.1-4; PGM 20.1-4, 13-19; 65.4-7; and 122.50-55.

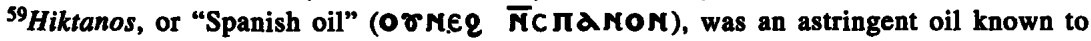
medical authors, originally of Spanish origin but not necessarily produced there; see Xavier Arce, "SPANIA, SPANOS-SPANH-SPANON on Papyri," Zeitschrift für Papyrologie und Epigraphik 61 (1985) 30-32; compare with item 23 below and Worrell, "Wizard's Hoard," 258 n. 4. The reference to two types of oil in the prescription suggests that either one could be used, depending on their availability.

${ }^{60}$ See Worrell, "Wizard's Hoard," 258 n. 5.

${ }^{61}$ On spells that induce insomnia in the victims of so-called love magic, see John Winkler, "The Constraints of Eros," in Faraone and Obbink, Magika Hiera, 225-26. 
(12) For one [7.5] who does not usually sleep with (a) woman: recite it / over some wine and have him drink it. ${ }^{62}$

(13) For one / in whom there is a worm: ${ }^{63}$ recite it / over some mint and make it into [7.10] a wreath for him.

(14) For the illness of / burning (lungs): ${ }^{64}$ recite it over some / wine, and have him inhale it(s fumes).

(15) For the / strep throat: recite it over some water / and sprinkle it down (his throat).

(16) For the one who [7.15] is gouty in the joints: ${ }^{65}$ recite / it over some ibis blood ${ }^{66}$ and / some wine, and smear them (with them).

(17) For one / who has a seizure: recite it over some oil / and anoint him.

(18) For one who is slow: [8.1] recite it over some pure olive oil and anoint him, / and write it on a clean papyrus sheet / and tie it to him.

(19) For a hemorrhage: [8.5] to stop it, recite it over some vinegar / and pour it over his head. ${ }^{67}$

(20) For those who / are estranged from one another: recite it / over some oil and anoint the face of one / of them. Let them look into the face of one [8.10] another so that they (both agree to) accept what you / say (and then) recite it over some rose oil $/$ and anoint your face. ${ }^{68}$

${ }^{62}$ The cure for this perceived problem (impotence, lack of interest, or homosexuality) is wine, suggesting that intoxication through a supposed alcoholic aphrodisiac would function as an effective cure. Prescription 28 similarly suggests that the infatuated person give wine to the person desired (the probable inhaling of wine fumes in prescription 14 is conceptually unrelated). Petronius (Satyricon 131) described a successful magical cure for impotence employing various rituals and colored threads. Magical cures concerned with male sexual potency are discussed under the rubric "erotic pharmacology" in Winkler, "The Constraints of Eros," 220-21, 237 n. 30. Wine was used as a cure by the Roman physician Asclepiades of Prusa (died ca. 40 BCE) as mentioned in Apuleius Florida 19.

${ }^{63}$ See Worrell, "Wizard's Hoard," 258 n. 9.

${ }^{64}$ Worrell ("Wizard's Hoard," 259 n. 1) surveys some possible identifications of this obscurely described malady, the "illness of burning (lungs)" (Tл I $\in \in \overline{\mathrm{M}} \kappa \omega Q \overline{\mathrm{T}}$ ).

${ }^{65} \mathrm{On}$ the treatment of gout in magical texts, see the discussion and literature cited in Kotansky, "Incantations and Prayers," 118-19, 134 nn. 84-85.

${ }^{66}$ On the ibis in magical texts, see $P G M 1.245-46 ; 2.46-47 ; 4.45-50,799-812,1689,2587$, 2649-54, 2685-89; 5.252, 375-80, 447-58; see also Hans Bonnet, Reallexikon der ägyptischen Religionsgeschichte (Berlin: de Gruyter, 1952) 162-64, 321; Alphons A. Barb, "Magica Varia," Syria 49 (1972) 343-70; and H. Idris Bell, Arthur Darby Nock, and H. Thompson, "Magical Texts from a Bilingual Papyrus in the British Museum," Proceedings of the British Academy 17 (1931) 235-87.

${ }^{67}$ On the use of vinegar in magical cures, see PGM 70.21 and prescription 23 below.

${ }^{68}$ This seems to be a ritual for reconciliation. See also the discussions on the holy man as social mediator in Brown, "Rise and Function of the Holy Man," 89-90, esp. n. 119. On the application of various concoctions to the faces of those who are in conflict socially, see PGM 7.179-80 and the other reconciliation ritual in prescription 29 below. 
(21) For / your enemies, that they (may) not prevail over you: / recite it over some water, adjuring [8.15] him [sic], and sprinkle your house and / every one of your (walk)ways.

(22) For your house, / and your sheep enclosure, and all that belongs to you: / recite it over some water [9.1] and sprinkle your house and every place / that belongs to you, (and) no evil ${ }^{69}$ will overtake you. /

(23) For a woman with an issue of blood: $:^{70} /$ recite it over some vinegar and pour it [9.5] over her head: recite it over some oil / of spanon and anoint her abdomen / and genitals. ${ }^{71}$

(24) For a merchant to profit: / recite it over some first-pressed oil / and sprinkle some merchandise (and) let [9.10] him take it with him abroad. ${ }^{72}$

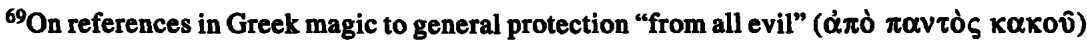
see the texts and literature cited in Daniel and Maltomini, Supplementum Magicum, 1. 6 lines 8-9.

${ }^{70}$ Although such a phenomenon as an issue of blood is generally considered to be dysfunctional (as in the case of the woman in Mark 5:24-34), there is evidence that the womb and its natural reproductive and cleansing processes were considered subject to unnatural human and supernatural interventions that sought to control its timely opening and closing, possibly in connection with solar or lunar theologies. Women's reproductive systems, therefore, were subject to the control of the ritualist; we cannot determine from this text, however, whether that control was a woman's choice. See also the study by Jean-Jacques Aubert, "Threatened Wombs: Aspects of Ancient Uterine Magic," GRBS 30 (1990) 421-49.

7 Prescription 23 employs two different sympathetic elements in two separate rituals (vinegar poured and oil anointed), suggesting the editor may have had knowledge of two different cures for the same illness, and simply included them both. Issues related to women's sexuality are referred to in PGM 7.260-71 (displaced uterus); 12a.9-10 (breast and uterus pain); 36.32032 (female contraception); 62.76-106 (a spell to cause menstruation); PDM 14.953-55, 96165, 970-84, 1196-98; and PGM 22a.2-9 (all are spells to stop menstruation or abnormal bleeding); a prescription apparently for an abortion is found in PDM 14.1188-89 (see Betz, Greek Magical Papyri in Translation, 249 n. 614); a curse against a husband for lack of child support is found in PGM 60.1-18 (see Betz, Greek Magical Papyri in Translation, 280, and the literature cited there concerning tomb desecrations); women's heterosexual and lesbian love spells are found in PGM 15.1-21 and 32.1-19. See also the discussions in Winkler, "The Constraints of Eros," 227-28, 240-41 nn. 73-77. On pennyroyal, lodestone, and other elements used in birthing, nursing, as female contraceptives, and abortifacients, see the informative discussions in Scarborough, "The Pharmacology of Sacred Plants, Herbs, and Roots," 144-45, 158-59.

${ }^{72}$ On spells for success in business endeavors, see the two lengthy spells in PGM 4.235972 and 2373-2440; and also those in PGM 8.35-63; 12.96-106; and 12.270-350. On the use of defixiones ("binding spells") to inhibit the commercial success of business rivals, see the discussion and literature cited in Faraone, "The Agonistic Context of Early Greek Binding Spells," 11. On spells for good weather for travellers, see the spell in PGM 28.1-10; the literature cited by Edward N. O'Neil in Betz, Greek Magical Papyri in Translation, 266; and the discussion in Smith, Jesus the Magician, 119, 199-200; see also PDM 14.1056-62 and $P G M$ 7.615-19. See further the discussion on beliefs and rituals of travellers who encounter crossroads in Sarah I. Johnston, "Crossroads," Zeitschrift für Papyrologie und Epigraphik (1991) 217-24, esp. 220 n. 16. 
(25) For the safety of ships at / sea or on the ocean / with everything (on board): write it on a clean papyrus / sheet and tie it [9.15] to the tip of the mast.

(26) For a / ruler to spare you / or (at least) not to spurn you: write it [10.1] on a papyrus sheet and make it into an / amulet, ${ }^{73}$ and tie it to your right / arm, and you will be spared. ${ }^{74} /$

(27) To cause a revelation to be given to you [10.5] in a dream: ${ }^{75}$ take some rocksalt / and place it under your head / as you are about to sleep, ${ }^{76}$ and you will be / informed about everything (concerning your inquiry).

(28) To cause someone / to desire you: recite it over some [10.10] newly-pressed wine and give it to him $^{77} /$ to drink.

(29) For your men / and the men of your village: / recite it over some oil and / anoint your face in their presence [10.15]. ${ }^{78}$

(30) For the safety of your house / and the walkways by your door: / recite it over some torrential water / and sprinkle your house and the [11.1] walkways by your door, and it will guard / you from every magical potion, and (will) / heal every disease, and (guard you from) every demon, / and every evil eye; ${ }^{79}$ and it [11.5] also will not allow estrangement to occur in your house, / nor (any) trouble (at all).

(31) For the evil eye / which is among domestic animals: recite it over some / oil and anoint them.

${ }^{73}$ The Greek term $\phi v \lambda \alpha \kappa \tau$ ก́piov ("phylactery") is used.

${ }^{74}$ See the comments concerning the relationship between political success and the blessing of the holy man in Brown, "Rise and Function of the Holy Man," 98 n. 221.

${ }^{75}$ On spells for dreams and dream oracles, see PGM 1.329; 4.2075-80, 3172-3208; 7.25054, 407-10, 740-55; and 8.64-110. See the collection of visionary reports by Arthur Darby Nock, "A Vision of Mandulis Aion," in Stewart, Essays on Religion, 1. 357-400; see also S. Eitrem, "Dreams and Divination in Magical Ritual," in Faraone and Obbink, Magika Hiera 175-87; and Luck, Arcana Mundi, 231-39 for a survey of primary texts.

${ }^{76} \mathrm{On}$ the ritual of placing sympathetic objects beside or under one's head before sleeping. see PGM 5.390-400; 7.748; and PDM 14.1070-77; and Eitrem, "Dreams and Divination in Magical Ritual," 177-79, 212; on the related ritual of burning salt and other elements before going to bed, see Graf, "Prayer in Magic and Religious Ritual," $196 \mathrm{nn} .64-65$.

${ }^{77}$ Unless the masculine gender is an instance of deliberate gender specific language (in which case we would have a rare homosexual love prescription), the masculine gender is probably another instance of a generalizing masculine formula that includes females.

${ }^{78}$ The anointing of the face is a common ritual for those who are at odds with each other, suggesting that here we may have another reconciliation ritual (see prescription 20) rather than a ritual for some type of protection for men.

${ }^{79}$ On the evil eye in magic, see PDM 14.1097-1103 and the literature cited in Betz, Greek Magical Papyri in Translation, 247 n. 590. Perhaps the earliest Greek literary reference to the evil eye in magic concerns Medea's use of the evil eye to curse the eye of the monster Talos in Apollonius of Rhodes Argonautica 4.1635-90 (ca. $250 \mathrm{BCE}$ ). For a bibliography of relevant anthropological and classical studies on the evil eye, see Winkler, "The Constraints of Eros," 235 n. 7. 
(32) For a woman whose milk does not flow: [11.10] recite it over something sweet, let / her eat it when she comes out / of the bath. ${ }^{80}$

You shall keep the / prayer in your mouth at all times, (and) no / obstacle will come [11.15] near you.

Before you use it / at any time, you must wash yourself with some laurel water, / be free from every defilement, / and (only) eat food which is clean, / (then) wash your mouth with some rocksalt [12.5] and some clean wine. I

ppppppp Fthp Fthp ${ }^{81}$ Oththsa / Tinou Ma Chhkslps Ml Chech / Phrlochnb Kskeks Phleelei / Nursksenfks Hnpsc Kskskeu [12.10] Okeps Ehos Fkeisndch / Pseochs Kfopsnth Cheura / Efkhk Shb[?]rs Othooaa / Thksbn Hthksbn Hthksbn / Hthksbn

[13.1] $\rho$ Come ${ }^{82}$ out of the four / winds of heaven, or (out of) the four corners, / with the spirits (who ride) the / breath-chariots ${ }^{83}$ of this great spirit. Extinguish [13.5] this chaos and this great / dragon and all his forms / and all his threats, he / who attacks this being of light, ${ }^{84}$ (and) / whose gates and windows [13.10] exist through him, / as well as his chambers, countless as they are. I

You ${ }^{85}$ cause the ordinances of this / great fiery servant / to guard the all! You are protected [13.15] by these great [14.1] angelic authorities!

${ }^{80}$ See the discussion for prescription 23, above. The "something sweet" ( is probably a reference to a honey-based candy. Bathing is part of the ritual for the client.

${ }^{81}$ Fth (Coptic: $\varphi \Theta$ or $\phi \Theta$, Greek: $\varphi \Theta$ ) is the abbreviation for the number ninety-nine, rep-

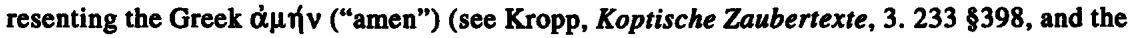
texts listed there), but the addition of a final $\pi$ to create the form $\varphi \oplus \pi$ indicates an anomalous form. Otherwise, the text was meant to begin "Amen, amen," but then continues with glossalaliac nonsense consisting mostly of juxtaposed consonants. The same text in P. Mich. inv. 603 has a single $\varphi \oplus \pi$ (presented in Worrell's text without comment). For a list of occurrences of "amen" in Greek magical texts not in PGM, see Daniel and Maltomini, Supplementum Magicum, 1. 23 lines 1-4. These nine lines of magical words contain four of the six Demotic letter symbols- 2 (hori, 7 times); $\varphi$ (fai, 6 times); + (ti, once); and $\sigma$ (chima, once)-which are absent from the concluding set of ninety-five lines of magical words and names.

${ }^{82}$ The following prayer introduces mythical elements and angelic and demonic beings whose identities and functions do not easily fit into the mythical cosmos so carefully and consistently described in the opening invocations of this long text (1.1-5.19). An unidentified god, not to be confused with "the Father" (14.5b-8), is summoned to come with his attendant spirits in order that they might extinguish this chaos along with an otherwise unidentified great dragon who attacks an unidentified being of light. No doubt an imaginative mind could integrate the two independent source texts theologically and cosmologically in a variety of ways.

${ }^{83}$ On the chariots of the gods in magical texts, see PGM 6.35-39; and Betz, Greek Magical Papyri in Translation, $111 \mathrm{n} .11$.

${ }^{84}$ Apparently the holy man's endearing name for his client.

${ }^{85}$ That is, the great Spirit whose virtues are praised seven times in this concluding aretalogical hymn. 
You, / whose beginning is first to leap / into the river of the ocean, ${ }^{86}$ shining / until the end ${ }^{87}$ through the burning of the trees [14.5] which are in all the world. ${ }^{88}$ You, the / heat whose strength results from / the longsuffering of the Father, / (who is) the Father of all the angels and archangels, / and all the powers, [14.10] the Father of heavenly and / earthly things, the Father of all that exist, / the Father of all the praises, / the Father of all the thrones / and their glory, the Father of all [14.15] lordships, the Father of / those who are in the abyss, the Father of the / holy majesties, the Father of / those who surround ${ }^{89}$ all humanity, [15.1] the Father of the judges, the Father of all the exalted powers, / the Judge of men! You, before / whose name one trembles and fears! [15.5] You, whom the ones in the heavens and on / earth adore! You, who founded / the crowns of the firmament! /

Mar Marak Louak Klouak / Amariak Marmarouak Bathi[15.10]ōrak Lōak «A〉nōak Marma/rathak Marmaōch Marmamath/masa Aksa S«aılōa Amarē/ thamia Chaōa Amachó Aōphi / Amabarbēs S‘àla Ōksa Ma[15.15]risēl Bēl Marma Rab Iaō / Abracha Abrassask Phnoun / Abouel Iaōth Baphra Nemoun [16.1] Outhilōri Kesisphia Eue Aiiphir / Kia Lithou Naomen Ebrapha / Erphaboiai Disios Akrakath / Echōi Chouchó Cheochchathie [16.5] Eie Ie

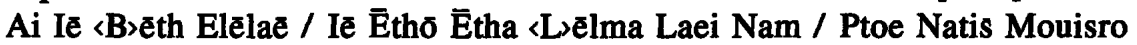
Saracha / Aeie Zēiōk Kaph Kaniph Ka/kris Rōm Biōrou Men Zeth[16.10]zêth Beth Zơch〉é Leth Cou Maru>/ahae Bōchōei Sabaẽ Metha / <Th〉onoun Thatho<u>m Erēboēl / «E〉reboēl Maralōè Amalōeith / <A〉cha Kaslōei Nararazoth [16.15] <E`naeibaōth Zēth Thala Laima / 〈A〉charmath Nebくab〉ain Baera / <A kra Char Kka<rch〉ōre Echora [17.1] Grama Akrameth Kramaram / Amamam Mam Kaleu Löeche $/$ Eueu Emaram Marthaō Thaōth/aōth Adonē

${ }^{86} \mathrm{Or}$ "the river (which leads to) the ocean"; as Morton Smith suggests (personal correspondence with the author, 1988), this is "probably an allusion to traditional speculation on the source of the Nile River which ultimately flows into the (primeval?) Mediterranean Ocean." Smith also points out the Aramaic nahara (the "river"; 19.12 and similarly the Greek ó $\pi 0 \tau \alpha \mu \sigma_{\zeta}$ ("the river") in Porphyry Epistula ad Anebonem 2.12b [= Eusebius Praep. Ev. 3.4.1-2]. This mythical topos is alluded to in the Greek amulet P. Haun. 3. 50; see the text, discussion, and literature cited in Daniel and Maltomini, Supplementum Magicum, 1. 8. A story with a similar mythic structure is employed by Virgil (Aeneid 4.450705): "Near the far end of the Ocean, where the sun sets, at the limits of Ethiopia, is a place where Atlas, the giant, turns on his shoulders the axle that is fitted to the sphere of the burning stars. A priestess of the Massylians who lives there. . . can stop the flowing of a river and turn the course of stars around."

${ }^{87}$ The beginning and end to the scheme seems to be limited to this sentence.

${ }^{88}$ The reference may be to "a setting star, like Sirius, signaling the beginning of summer, since its heat (mentioned here and in the next sentence) burns all of the trees" (observation by Morton Smith, personal correspondence with the author, 1988).

${ }^{89}$ Here the unidentified angels surround all humanity, while in the first text they surround the unknowable Pantocrator (1.9). 
Elōaei Elōaei [17.5] Elōaei Amarachō Eblamabla<m> / Athanama Natha Altha Nathan / Abriōchs Ōchōch Chiōcha Iō / Chae Klasēu Maōth Chie Chrou / Thōa Thouthōth Routh Thapsae [17.10] Psarouēl Iaēl Ioẽl Marma / Rōthōan Anaēl Athanaęl / Naęl Nachơiơth Nena Thara/êl Thariēl Chōa Arichō Rachōe / Amalaria Basēm Basēma [17.15] Adōnaei Elōlei Saōthba / Sabaoth Aó Aóabraōa / Cheimarmen Ae Chararar [18.1] Chararan Larouth Rourouth Outh / Ēthith Chōchōō Iciō Salpsō / Lampsơ Rơthēri Ēleilam Eiela/eilath / Kaki Macharima Elth [18.5] Ëlth Eithinalam Eue Thalasou / Thour Michikl Michtham Eltha Iēe / Lamneu Alēth Soumaria Southa / Ēu Soulothia Thōphonia Drem / Phanaēl Abratha Marmarel [18.10] Thanael Akōl Ia Eo Ia Ēa / Iopothen Athamao Athie Io/iola Philathe Cho Cho Chó / Cho Sathẽa Iaél Ea Palak / Palameth Pith Pithae Pichōra [18.15] Sothae Pithoth Eialael Louam / Ethalaetha Ëthal Thaloêou / Teue Eue Psee Droath Thaeieth [19.1] Eleil Iakneu Ithoa Tremouth / Eabrath Abrath Iathoth Sesēkin/barphakēs Arbeleơadōnai / Ōnb Abrachơtha Abrasēnathơthơ [19.5] Abbia Elōa Marithchari Ioth Eea / Phorou Lōam Elea E Lol Iel Ebre / Baẹl Rẽm Phanouel Pebrēstēr / Naggelos / Phanouēl Michaēl Chilath / Iaó Aẽ Ple Ōa Iêl Elemour [19.10] Riēl Riēl Lala Aơ Lōlam / Elsēl Labothiaēl Aơtha Aēl Ēaē / Iath Ithe Iaō Ōth Keenath Geneen / Aēl Mariao Miriō Marithiōth Eōa / Thalēath Marmariariōth Arióa [19.15] Euaria Rara Epikēm Phthēara Chara / Raē Phthēsēkere Abrabathan[20.1]alba Alaō Ala[o] Alamari Mari / Achēl Neēl Semesi Emieueai / Ilam Semesi Lam Abrasak / Abramachamari Mana Chamari [20.5] Akracharan Ēl Ël Chaēl Phanaēl / Phanouel Akrael Mari Soumenzeth/zoucheleth Lêth Thalathaakōthbi / Leth Dinamieel Eênm Bibtou / Anaẽl Lath Ainatha Ēphiephieph [20.10] Kōthōōth Chơth Eleaph Aphẽra / Lathkiloch Phrenemoun / Ōthiōrithe Laó [Ō]asmouth Phabouea / Bōeaielōaeisamabrachthēs Alaōksa / Phrecchó Eneuōth Riso Isath Kalath [20.15] Achath Theram Aslam Pechōr Mōrpheōth / Mouphiath Morphilab Morphilab Rōth Phil/ōphilathoth Ēêe Ēo Phila Eeo Phanoeo Anolbiba. ppp

\section{Commentary.}

The structure of the two texts: The text appears to be a compilation of traditional materials from a variety of sources. It opens with a lengthy prayer (1.1-4.14a) which includes the standard invocations, credentials, and requests. ${ }^{90}$ The invocations are directed to an unnamed highest deity (1.1-11) and the seven archangels (1.14-16a); the credentials are those of the holy man $(1.16 c-2.2 ; 3.11-17 a ; 4.1 b-8 a)$; and his requests are not specific $(1.12-13,16 \mathrm{~b} ; 2.15 \mathrm{~b}-3.10)$. The prayer includes a traditional list

\footnotetext{
${ }^{90}$ See the study on the structure of prayer in the magical tradition in Graf, "Prayer in Magic and Religious Ritual," 188-213.
} 
of twenty-one angels with Hebrew names followed by a description of their functions (2.3-9a, 9b-15a), as well as two editorial comments, or glosses, concerning ritual purity $(3.17 \mathrm{~b}-4.1 \mathrm{a} ; 4.8 \mathrm{~b}-14 \mathrm{a})$. The prayer is objectively referred to as an $\varepsilon \dot{u} \chi \eta^{\prime}(1.12 ; 3.8 \mathrm{~b}-9 \mathrm{a} ; 4.5 \mathrm{~b}-6 \mathrm{a}$ [plural]; 11.13), and variously described as powerful $(3.13 ; 4.14 \mathrm{~b})$, capable of action $(3.15 ; 4.4$; $4.17)$, something performed $(3.17 ; 4.9 ;$ a "response" or "request" in 5.8-9), something recited (4.14), highly honorable and of great virtue (5.9-10), efficacious (5.11-19a), something recited only in ritual purity (3.10-12; $3.17 \mathrm{~b}-4.1 \mathrm{a} ; 4.8 \mathrm{~b}-9 ; 5.3-8 ; 11.15 \mathrm{~b}-12.1-5)$ and in conjunction with specific ritual actions $(1.12-13 ; 4.13-16 ; 5.19 b-11.12 a)$, containing secret names (4.6, 10-11), Hebrew names (3.6-7), and Hebrew words (3.14) in the language of heaven (that is, Hebrew; 3.7).

A series of ritual instructions and promises, which include a ritual involving the ingestion of a hawk's egg fried over honey, follow the prayer (4.14b-5.19a). These ritual instructions are followed by a traditional list of thirty-two tricks and prescriptions (4.19b-11.12a), ${ }^{91}$ and further instructions, promises, and ritual preparations $(11.12 b-12.5)$. The first text apparently concludes at $\mathbf{1 2 . 5}$ and is followed by a single line of scribal decoration that functions as a text separator, signaling the end of the first text.

The second text begins with seven tau-rho staurograms ${ }^{92}$ and continues with nine lines of magical words (12.6-14) introducing the invocational prayer (13.1-15.7) which assumes a different mythological structure than the preceding materials. ${ }^{93} \mathrm{~A}$ lengthy section of magical words, ninety-five lines long (15.8-20.18), follows the invocation.

\footnotetext{
${ }^{91}$ Such lists of tricks and medical prescriptions are common in the magical tradition; see, for example, PGM 7.167-86 (and the literature cited for that text in Betz, Greek Magical Papyri in Translation, 120); PGM 13.235-335; PDM 14.74-90; PGM 121.1-14; and PGM 127.1-12.

${ }^{92}$ A single tau-rho staurogram ( $($ ), a standard Christian scribal abbreviation for ỏ $\sigma \tau \alpha v \rho o ́ s$ ("cross"), is found in this codex at the beginning of the invocation (13.1); three staurograms are found at the end of the last line of the book (20.17); see Erich Dinkler, Signum Crucis (Tübingen: Mohr/Siebeck, 1967) 177-78; Kurt Aland, "Bemerkungen zum Alter und zur Entstehung des Christogrammes," in idem, Studien zur Überlieferung des Neuen Testaments und seines Textes (Berlin: de Gruyter, 1967) 173-79; and Wolfgang Wischmeyer, "Christogramm und Staurogramm in den lateinischen Inschriften altkirchlicher Zeit," in Carl Andresen and Günther Klein, eds., Theologia Crucis-Signum Crucis: Festschrift für Erich Dinkler (Tübingen: Mohr/Siebeck, 1979) 539-50.

${ }^{93}$ Worrell ("Wizard's Hoard," 261 n. 7) condescendingly refers to the prayer as a "hymn (which) is nonsense, and was nonsense to our magician." Alan F. Segal ("Hellenistic Magic: Some Questions of Definition," in R. van den Broek and M. J. Vermaseren, eds., Studies in Gnosticism and Hellenistic Religions [Leiden: Brill, 1981] 351-53) discusses scholarly attitudes towards hymnic passages in magical texts. Fritz Graf ("Prayer in Magic and Religious Ritual," 188-213) has convincingly demonstrated that prayer language in magical texts indicates normative religious sentiments and values, challenging the classic Frazerian dichotomy between magic and religion. See also the useful discussions in Harold Riesenfeld, "Remarques sur les hymnes magiques," Eranos 44 (1946) 153-60.
} 
The thirty-two tricks and medical prescriptions: The majority of the thirty-two tricks and medical prescriptions involve reciting the prayer (1$17,19-24,28-32)$ or copying it onto papyrus amulets $(18,25-26) .{ }^{94}$ Most often, the prayer must be recited over the specifically prescribed sympathetic elements, such as oil or water, ${ }^{95}$ in order to enchant them, after which those elements are to be applied in various fashions, such as anointing, washing, or drinking. The thirty-two items in the list cover a broad variety of concerns including cures for physical and psychological ailments $(1-11,13-19,23,28-29,32)$, guarantees for success in a variety of social relationships $(12,20-21,26,28-29)$ and business endeavors (24-25), guarantees for the protection of property $(22,30)$ and protection from evil $(30$ 31 , and a single guarantee for personal revelations through dreams (27).

Several of the healing prescriptions include the use of sympathetic elements, or concoctions of such elements, which are either ingested (1-3, and 32 ) or applied topically as enchanted ointments $(5-6,8,14-16,23)$. Some of these topical applications may be ritual anointings or placebos ${ }^{96}$ with no medicinal benefit, while others may reflect a more scientific approach to the topical application of healing balms and medicaments $(14-16,23)$. In any case, this text evinces little knowledge of the healing methods from the learned medical profession that one finds, for example, in the tradition of Galen (died ca. $200 \mathrm{CE}$ ) or in the indigenous traditions of Egypt. ${ }^{97}$

The absence of exorcism as a cure for physical and psychological ailments should be noted. Except for an obscure reference to protection "from every (evil) thing" (5.17), the only possible exorcistic feature is contained in the prayer of the second text: "extinguish this chaos and this great dragon and all his forms and all his threats" (13.5-7). Some of the tricks

\footnotetext{
${ }^{94}$ The two exceptions are item 7 where the recurring phrase "recite it over" has apparently dropped out through a copyist's error, and item 27 where no reference is made to the prayer or its ritual recitation. In this last instance, one would expect the prayer to be recited over the rocksalt (see 12.4-5); its absence probably is due to accidental omission.

${ }^{95}$ Such sympathetic elements, especially human substances like hair, are referred to as ov $\sigma i$ in in the Greek texts (for example, PGM 1.99; on ovof $\alpha$ in the magical papyri, see Karl Preisendanz, "Miszellen zu den Zauberpapyri, I," Wiener Studien 40 [1918] 1-8, esp. 5-8). The word does not occur in Kropp's Greek index for the Coptic papyri, but is briefly discussed in the second volume (Koptische Zaubertexte, 2. 110-13). See the discussions on sympathy in Preisendanz, "Miszellen, 1," 2-5; and Hopfner, Offenbarungszauber, 1. 667-77.

96" Many [forms of healing] are connected with the administration of an innocuous placebo that is charged with the blessing of the holy man. The blessing gives reality and efficacy to what were thought of as the inscrutable workings of providence" (Brown, "Rise and Function of the Holy Man," 96).

${ }^{97}$ Walter C. Till, Die Arzneikunde der Kopten (Berlin: Akademie-Verlag, 1951). See also Ludwig Edelstein, "Greek Medicine in Relation to Religion and Magic," Bulletin of the Institute of the History of Medicine 5 (1937) 201-46; and Robert K. Ritner, The Mechanics of Ancient Egyptian Magical Practice (Chicago: Oriental Institute of the University of Chicago, 1993) and the literature cited there.
} 
in the list of thirty-two items, however, suggest that their purpose is to keep away evil spirits by sprinkling an area with enchanted water (11, 21$22,24,30) .{ }^{98}$

The list of prescriptions is loosely constructed according to thematic and catchword associations. The first nineteen prescriptions concern physical and psychological problems, suggesting that the first nineteen items may have comprised one of the primary sources used in the compilation of the larger list. The notable exception is item 12 , which does not refer to a physical or psychological problem, but is included at this point through a catchword association - that of sleep-with the preceding item and so might be a secondary interpolation into an earlier source list. This proposed earlier list of eighteen items is loosely arranged according to the part of the body affected. Items 4 and 5 refer to abdominal problems, while items 6 through 9 refer to problems believed to be related to the head. Items 10 and 11 reflect psychological and behavioral problems related to the evening hours (fear of dark and irregular sleep) into which item 12 is interpolated, as noted above. Items 14 and 15 refer to breathing problems, while items 17 and 18 refer to perceived mental disorders affecting motor control.

At this point the list moves beyond concerns for physical and psychological problems. Items 20 and 21 refer to social conflict, while item 22 refers to the protection of one's house, sheep enclosures, and property and is probably thematically related to the preceding item, which refers to protection against one's enemies. Items 21 and 22 appear to have been conflated in item 30.

Items 24 and 25 refer to concerns for merchants, specifically, guarantees for financial profit and safety in water transport. Item 26, which guarantees political favor, is also related to the travelling merchant's concerns for political safety while travelling abroad.

Items 27 through 32 seem to be a concluding set of loosely related tricks and medical prescriptions which deal with personal revelations given through dreams (27), a concern for love (28), general concerns for "your men and the men of your village" (29), protection of one's house and walkways (30), ${ }^{99}$ protection from the evil eye (31), and healing for "a woman whose milk does not flow" (32). Items 30 and 31, related through the catchword of the evil eye, apply to humans (30) and animals (31). Although not clustered together, items 32 and 23 are both concerned with female medical concerns (menstruation or hemorrhage, as well as lactation; women are also specifically mentioned in item 12), and it is striking that women are mentioned only in relation to their functions as sleeping partners (12) and to their reproductive capacities $(23,32)$.

${ }^{98}$ On the ritual of cleansing an area with enchanted water, see PDM 14.481-83, 843-45.

${ }^{99}$ Compare item 30 to items 21-22. 
The thirty-two items are also interrelated according to the sympathetic elements employed (water, oil, vinegar, mint, figs, wine, ibis blood, rocksalt, candy) and the associated activity (wash, drink, anoint, pour, bind, wear, eat). Items 2 and 3 refer to the drinking and then washing in laurel water and the obscure brick water. Items 5 through 9 employ oil for anointing (5 and 6 refer simply to oil, while items 8 and 9 refer specifically to firstpressed oil). Item 10 refers to washing in rainwater and item 11 , simply in water. Item 17 refers to anointing with oil; item 18 refers to anointing with pure olive oil. Items 21 and 22 refer to the sprinkling with water of "your house and every one of your walkways" (21) and "your house and every place that belongs to you" (22). Items 25 and 26 refer to the manufacture of papyrus amulets that contain the text of the spell: item 25 states, "write it on a clean papyrus sheet and tie it to the tip of the mast"; and item 26 reads, "make it into a phylacterion, and tie it to your right arm." 100

The preceding observations on the thematic and catchword arrangement of the list suggest that it is a conflation of earlier source materials. The first nineteen items (perhaps without the later interpolated item 12) may have derived from an already integrated source primarily concerned with physical and psychological problems. A series of thirteen diverse items (20-32) then followed; these show specialized concerns for a variety of social and political relationships, business concerns, the protection of property, and protection from evil, including a single item for personal revelation and two items reflecting medical concerns specific to women. This concluding series of thirteen diverse items represents a clustering of traditional units according to themes and catchwords and may have been added secondarily to the preceding nineteen items, which may have derived from an earlier source dealing with physical and psychological concerns.

The Cosmological Symbolism: The opening invocations in the text suggest some of the basic features of the orderly cosmological myth assumed by its author. The author is certainly familiar with numerical symbolism common in religious texts from antiquity. The numbers employed typically serve to create order in humanity's experience of its environment. There is one highest deity (the Pantocrator), and twenty-one angelic powers (in three groups of seven, six, and eight). The holy man purifies himself for a period of forty days; the prayer initially is recited over honey and licorice root seven times, and the god comes out of the four winds, the four corners. ${ }^{101}$ This orderliness of the human and divine environment reflected in numeri-

${ }^{100}$ See the papyrus amulet employed in prescription 18.

${ }^{101}$ See the discussion and literature cited by Adela Yarbro Collins, "Numerical Symbolism in Apocalyptic Literature," in ANRW 2. 21/2 (1984) 1221-87. See also Hans G. Gundel, Weltbild und Astrologie in den griechischen Zauberpapyri (Munich: Beck, 1968). 
cal symbols is coupled in the text with a theory of purity and impurity that further serves to order human experience. ${ }^{102}$ The requirement for ritual purity is stressed repeatedly and its fulfillment is crucial to the efficacy of the prayer and the ritual actions. The concern for order in human experience is especially reinforced by the rebuke of "chaos" ( $\chi \alpha \dot{\alpha})$ ) in the opening lines of the second prayer.

The orderly cosmos is divided into two levels, that of the unclean world below, in which the human drama is played out (the locus of the holy man and his client), and that of the spiritual world "in the height," populated by the aeons of light and the almighty Pantocrator. The "one who activates the prayer," the only self-designation of the holy man in the text, invokes the Pantocrator in order that the supplicant's requests will be answered. The Pantocrator is surrounded by the twenty-one angelic powers or great ones who are appointed over his work and service, and so carry out his will in response to the requests of the holy man, now divinized as the authoritative and heavenly "Seth the son of Adam."

The twenty-one powers are comprised of three levels of angelic beings: the seven archangels, the eight ministrants, and the six authorities. The "one who activates the prayer" three times identifies himself with the heavenly "Seth the son of Adam," and so has authority over the seven archangels and the other fourteen powers; they will bring to pass everything that the Pantocrator has granted to the holy man as he makes his requests known, "performs the ritual in purity," and recites the efficacious prayer.

Because the holy man identifies with "Seth the son of Adam," he has access to "the virtues and the mysteries" that Seth received from his father Adam. The prayer that the holy man possesses in this text also contains "secret names. . . Hebrew names. . . Hebrew words," which are in "Hebrew, the language of heaven." According to the myth, the holy man presented several claims - that he can communicate effectively with angels in their heavenly language, ${ }^{103}$ that he knows and can pronounce their secret names, ${ }^{104}$ and that he has access to the revelations given to biblical Seth

${ }^{102}$ Mary Douglas, Purity and Danger (London: Routledge \& Kegan Paul, 1966) esp. 2-3. On ritual purity see Eitrem, "Dreams and Divination in Magical Ritual," 177.

${ }^{103}$ Paul apparently knew of Christians in midfirst-century Corinth who made the same claim (1 Cor 13:1).

${ }^{104} \mathrm{The}$ use of names in this text is typical, although noteworthy. In reference to the "Pantocrator," the opening lines of the text clearly state that only he knows his own name. When the divinized holy man says that he is "Seth the son of Adam," he ranks himself above the twenty-one angelic powers; when he speaks their names in the following lines, he demonstrates the secret knowledge that he has received and that gives him power over them: "after an invocation, it is common for the speaker to declare his exalted identity in order to secure obedience" (observation by Morton Smith, personal correspondence with the author, 1988). See the discussion in Graf, "Prayer in Magic and Religious Ritual," 191-94. 
from his father Adam; these provide the holy man with the necessary authority over the twenty-one angelic powers. He could then expect that they would carry out the work which the Pantocrator has granted to the holy man. ${ }^{105}$ The ultimate promise of the prayer for the holy man who activates it and for his client is that the problematic human condition, plagued by social dysfunction and physical and psychological maladies, can be overcome by direct access through the holy man to the highest heavenly being, the "God, Lord Lord, Pantocrator," of the text's opening lines.

The magical words (voces magicae): One can isolate well-known magical words and names, as well as derivations and new forms, in the one hundred and four lines of voces magicae. Only the most obvious or striking are noted in this study. 106

The common word Akrammachamarei ${ }^{107}$ is written in the variant form Abramachamari, followed by Mamna and the derivation Chamariakracharan (20.4-5).

There are two variant forms of the well-known palindrome Ablanathanalba. ${ }^{108}$ It is written as Athanamanatha (in the derived, jumbled series Eblamablam Athanamanatha Alba Nathan [17:5-6]) with consonantal shifts from $B \lambda$ (and $\lambda B$ ) to $\theta$, and from $\theta$ to $M$. The word is also written in the more typical form Abranathanalba where the third letter exhibits a standard consonantal shift from $a$ to $p(19.16-20.1)$.

${ }^{105}$ In contrast to a widely held conception, Graf has shown ("Prayer in Magic and Religious Ritual," 192, $210 \mathrm{nn} .32-35$ ) that the magical words and names "are not used. . . to force the divinity: they take the place of, and serve as, the [holy man's] credentials, an ample display of knowledge. ... The papyri state that these names were secret, that the god enjoys being called by them and helps [the holy man] out of joy."

${ }^{106}$ The four scribes who copied these magical words (or the scribe of their source) often added spaces in the middle' of words and names and also connected words and names by omitting spaces where one would expect them. This introduces a considerable amount of variation in the forms of some words and names.

${ }^{107}$ Kropp, Koptische Zaubertexte, 3. 123 \&202: $\alpha \gamma \rho \alpha \mu \mu \alpha \chi \alpha \mu \alpha \rho \mathrm{O}$. On the possible derivation of the name from Hebrew, see Gershom Scholem, Jewish Gnosticism, Merkabah Mysticism, and Talmudic Tradition (2d ed.; New York: Jewish Theological Seminary of America, 1965) 94-100. See the list of occurrences of this word in Greek magical texts not included in PGM in Daniel and Maltomini, Supplementum Magicum, 1. 10 line 1. For akpdMaXa Map in two Coptic magical texts, see Walter Beltz, "Die koptischen Zauberpergamente der Papyrus-Sammlung des Staatlichen Museen zu Berlin," Archiv für Papyrusforschung 30 (1984) 94 [P. 8328]; and idem, "Die koptischen Zauberpapiere und Zauberostraka der Papyrus-Sammlung der Staatlichen Museen zu Berlin," Archiv für Papyrusforschung 31 (1985) 32 [P. 11347].

${ }^{108} \mathrm{Kropp}$, Koptische Zaubertexte, 3. 122 \&201: $\alpha \beta \lambda \alpha v \alpha \theta \alpha v \alpha \lambda \beta \alpha$. See the literature cited and a list of texts not included in PGM in Daniel and Maltomini, Supplementum Magicum, 1. 9 lines 1-7. The word is not listed in Walter Beltz, "Die koptischen Zaubertexte der PapyrusSammlung der Staatlichen Museen zu Berlin: Register," Archiv für Papyrusforschung 32 (1986) 57. 
One of the longest known palindromes, often abbreviated in various forms, is the Iaeobaphrenemoun formula. In its complete form it is written in Greek texts as aeobaphrenemouniothilarikriphiaeueaipirkiralithounuomenerphaboeai. In our Coptic text (15.17-16.3), it is an imperfect palindrome in a slightly longer form: Iaōthbaphranemounouthilorikeiphiaeueaiiphirkialithounaomenebraphaerphaboiai. 109

The well-known Abrasax (or Abraxas) ${ }^{110}$ is written in the forms Abrasak $(15.16,20.3)$ and the probable derivations Abracha (15.16), Abratha (18.9), and Eabrath Abrath (19.2). The common word Sesengenbarpharanges occurs once in the form Sesekinbarphakēs (19.2-3) but without its usual accompanying term, Ablanathanalba. ${ }^{111}$ The common word Semesilam ${ }^{112}$ also occurs once but is preceded by the derived jumble Semesi Emieueai Ilam (20.2-3).

Several angelic names derive from various Hebrew names for the highest God. Ia $\sigma^{113}$ is written three times $(15.5 ; 19.9,12)$. Iao is derived from Iaōth- (15.17) which occurs at the beginning of the text's longest palindrome (the Iaeothbaphrenemoun formula discussed above) and may be a contraction of Iaō and Sabaōth. ${ }^{114}$ Adōnē (followed by Elōaei Elōaei Elōaei in 17.4-5) is derived from Adonnai ${ }^{115}$ and often accompanied by Iao, Elōai, ${ }^{116}$

${ }^{109}$ This is the only occurrence of the word known to me in Coptic texts. Both of these long forms incorporate the shorter Baphrenemoun formula. Compare Kropp, Koptische Zaubertexte,

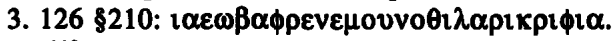

${ }^{110}$ See the concise discussion and the literature cited in Betz, Greek Magical Papyri in Translation, 331, "ABRASAX"; see also Walter Beltz, "Die koptischen Zauberpapyri der Papyrus-Sammlung der Staatlichen Museen zu Berlin," Archiv für Papyrusforschung 29 (1983) 62 [P. 5565] and 84 [P. 15990]; on the form "abraxas," see Kropp, Koptişche Zaubertexte, 3. 123 8203: $\alpha \beta \rho \alpha \chi \alpha$ 5. On the form "abraxax," see Beltz, "Zauberpergamente," 89 [P. 8109].

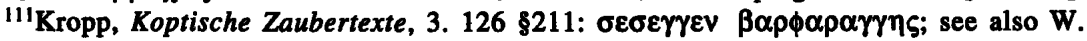
Fauth, "SSM PDRSSA," ZDMG 120 (1970) 229-56, esp. 254-55. See the literature cited and a list of texts not included in PGM in Daniel and Maltomini, Supplementum Magicum, 1. 10 line 2. The word is not listed in Beltz, "Register," 63.

${ }^{112}$ Kropp, Koptische Zaubertexte, 3. $125 \$ 207: \sigma \varepsilon \mu \varepsilon \sigma 1 \lambda \alpha \mu$. See the literature cited and a list of texts not included in PGM in Daniel and Maltomini, Supplementum Magicum, 1.10 lines 4-5. The word is not listed in Beltz, "Register," 64.

${ }^{113}$ See the concise discussion and the literature cited in Betz, Greek Magical Papyri in Translation, 335 (s.v. IAO). See the occurrences of the word in Beltz, "Zauberpapyri," 79-80 [P. 10587], 84 [P. 15990], and idem, "Zauberpergamente," 95-96 [P. 8503], 98-99 [P. 9074], 103-104 [P. 20911].

${ }^{114}$ The Hebrew plural ending $m$ was freely added to other letter combinations to create false Hebrew words or magical neologisms. On the creation of bogus Hebrew words, see the discussion in Brashear, Magica Varia, 22, and the literature cited there.

${ }^{115}$ See the concise discussion and the literature cited in Betz, Greek Magical Papyri in Translation, 331, "ADONAI" and "ADONAIOS"; see also Beltz, "Zauberpapyri," 79-80 [P. 10587].

${ }^{116}$ See the concise discussion of the Greek form and the literature cited in Betz, Greek 
and/or Sabaoth, while Adonaei is followed by Eloaei and the jumbled form Saothba Sabaoth ${ }^{117}(17.15-16)$ and is apparently joined with Arbeleo in Arbeleōadōnai (19.3). The alpha-omega name $A \bar{o}^{118}$ is written alone twice (17.16, 19.10), and in expanded forms as Aoth (17.4), ${ }^{119}$ Aotha (19.11), Aopphi (15.13), in reverse as Ōa (19.9), and in the palindrome Aōabraōa (17.16).

Other magical names and words also occur, but in variant forms, like Marmaru' ${ }^{120}$ or Marmaraoth, ${ }^{121}$ either of which may be the base for the derivative forms Marmarouak (15.9), Marmarathak (15.10-11), and Marmarel (18.9). Bathuriel ${ }^{122}$ shares the base for Bathiorak (15.10-11). Sabael ${ }^{123}$ possibly occurs as Sabae (16.11). Chara occurs alone once (19.15) but is employed in several combinations. ${ }^{124}$

Popular angelic names with -êl suffixes ${ }^{125}$ occur frequently and repeatedly, but some may be freely created neologisms, such as Marisēl (15.1415), Bèl (15.15), Abouēl (15.17), the geminate Ereboēl Ereboel (16.12-13), Psarouel Iaèl Ioēl (17.10), Anael Athanaêlnaēl (17.11-12), Tharaêl Thariel (17.12-13), (Drem-[?]) Phanaêl (18.8-9), Marmarēl Thanaēl (18.9-10), Iaẽl (18.13), Eialaēl (18.15), Iêl (19.6), Baēl (19.7), Phanouêl. . . Phanouêl Michaēl (19.7-8), Iēl (19.9), the geminate Riēl Riēl (19.10), Elsēl (19.11), Labothiaēl (19.11), Aēl (19.11, 13), Achēl Neēl (20.2), the series Ēl Ēl Chael Phanaēl Phanouel Akraēl (20.5-6), Dinamieel (20.8), and Anaēl (20.9).

The two biblically significant place names of Nazareth and Samaria were apparently used to create Nararazoth (16.14) and Soumaria ${ }^{126}$ (18.7). The names of letters in the Hebrew alphabet are similarly employed in Aleth (perhaps referring to the Hebrew $\$ ; 18.7$ ) and Bêth ${ }^{127}$ (Hebrew $ב ; 16.5,10$ ).

Magical Papyri in Translation, 334, "ELOAIOS"; see also "ELOEI" in Beltz, "Zauberpapiere und Zauberostraka," 32 [P. 11347].

${ }^{117}$ The full form of Iao Adonai Eloai Sabaoth often occurs as a unit in early Jewish and Christian literature; see Kropp, Koptische Zaubertexte, 3. $128 \$ 217$.

${ }^{118}$ Kropp, Koptische Zaubertexte, 3. $84 \$ 145$ and $215 \$ 367$. On Ao, see the useful discussion and bibliography by Gerhard Kittel, "A $\Omega$ " TDNT 2 (1964) 1-3.

${ }^{119}$ See Beltz, "Zauberpergamente," 99 [P. 9074].

${ }^{120} \mathrm{Kropp}$, Koptische Zaubertexte, 3. 32848.

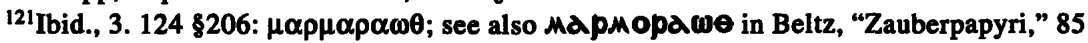

[P. 15990]; and MapMaprw in idem, "Zauberpapyri," 75 [P. 8326]; and idem,

"Zauberpergamente," 100 [P. 11918].

${ }^{122}$ Kropp, Koptische Zaubertexte, 3. $32 \$ 48$.

${ }^{123}$ Ibid., 3. 78 \&137.

${ }^{124}$ Chara was the traditional mother of Gabrilia; see Kropp, Koptische Zaubertexte, 2.63 (London MS OR. 6948[2]).

${ }^{125}$ All such names end in the Greek $-\eta \lambda$, except Marmarel and Dinamieel, which end in $-\varepsilon \lambda$. ${ }^{126}$ See also Soumarta in PGM 2.116; 4.947, 1805, 3158, and 8.82; see Scholem, Jewish Gnosticism, 86, 89, 94-95.

${ }^{127}$ Kropp, Koptische Zaubertexte, 3. $85 \$ 146$ and $132 \$ 227$. 
Aslam (20.15) may be based on the consonantal triad s-1-m which is shared by the Hebrew (shalom) and the Arabic (islam).

Greek words, moreover, are possibly seen in the text: Salpso Lampso (18.2-3) may be one word, a corrupted and mnemonic form of $\sigma \alpha \lambda \psi \omega-$ $\lambda \alpha \mu \psi \omega$ ("Trumpet-Lamp" or "Shining-Trumpet"). Pithae (18.14) could represent $\pi \mid \theta \alpha \eta$ ("Pythia"), the famous oracular priestess at Delphi. Psēe (18.17) may refer to the twenty-third letter of the Greek alphabet $\psi$, and Naggelos

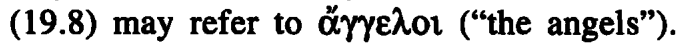




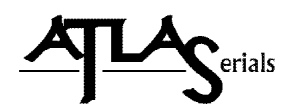

Copyright and Use:

As an ATLAS user, you may print, download, or send articles for individual use according to fair use as defined by U.S. and international copyright law and as otherwise authorized under your respective ATLAS subscriber agreement.

No content may be copied or emailed to multiple sites or publicly posted without the copyright holder(s)' express written permission. Any use, decompiling, reproduction, or distribution of this journal in excess of fair use provisions may be a violation of copyright law.

This journal is made available to you through the ATLAS collection with permission from the copyright holder(s). The copyright holder for an entire issue of a journal typically is the journal owner, who also may own the copyright in each article. However, for certain articles, the author of the article may maintain the copyright in the article. Please contact the copyright holder(s) to request permission to use an article or specific work for any use not covered by the fair use provisions of the copyright laws or covered by your respective ATLAS subscriber agreement. For information regarding the copyright holder(s), please refer to the copyright information in the journal, if available, or contact ATLA to request contact information for the copyright holder(s).

About ATLAS:

The ATLA Serials (ATLAS $®)$ collection contains electronic versions of previously published religion and theology journals reproduced with permission. The ATLAS collection is owned and managed by the American Theological Library Association (ATLA) and received initial funding from Lilly Endowment Inc.

The design and final form of this electronic document is the property of the American Theological Library Association. 